\author{
Sławoj Tanaś \\ Instytut Geografii Miast i Turyzmu \\ Uniwersytet Łódzki \\ 90-142 Łódź, ul. Kopcińskiego 31 \\ slatan@geo.uni.lodz.pl
}

\section{PERCEPCJA ŚMIERCI W TURYSTYCE KULTUROWEJ}

\section{THE PERCEPTION OF DEATH IN CULTURAL TOURISM}

\begin{abstract}
Zarys treści: Celem autora artykułu jest przedstawienie roli, jaką śmierć (jej wyobrażenia, symbolika i skutki) odgrywa w kształtowaniu społecznej przestrzeni turystycznej. Zaprezentowana została historia percepcji śmierci w ujęciu poznawczym oraz podano przykłady miejsc związanych ze śmiercią, będących przedmiotem zainteresowań turystycznych. Autor podejmuje próbę odpowiedzi na pytanie: dlaczego turysta odwiedza miejsca związane ze śmiercią?
\end{abstract}

Słowa kluczowe: turystyka kulturowa, śmierć, tanatoturystyka.

Postępujący wzrost zainteresowania podróżami motywowanymi chęcią poznania nie tylko zabytków, ale również bardziej delikatnych elementów kultury niematerialnej, takich jak tradycja, obrzędy i wierzenia skutkuje tworzeniem nowych produktów turystycznych, niejednokrotnie wzbudzających kontrowersje. Sfera dziedzictwa kulturowego ocierająca się o sacrum, podlegająca czci i ochronie przed ingerencją obcych dla danej kultury elementów, jest współcześnie pozbawiana mistycyzmu, np. poprzez postępującą komercjalizację życia.

Turystyka jest zjawiskiem, podczas którego turysta wchodzi w styczność osobistą ze środowiskiem odwiedzanym, m.in. kulturowym i społecznym, tym samym jest spotkaniem kultur, wymianą wartości pomiędzy turystami a mieszkańcami, jest niejednokrotnie czynnikiem przemian społecznych i kulturowych (PRZECŁAWSKI 1997). Jednym $\mathrm{z}$ istotnych elementów kultury jest śmierć, przez wielu uznawana za czynnik, któremu zawdzięcza się powstanie i istnienie kultury. Artykuł jest próbą przedstawienia roli, jaką śmierć (jej wyobrażenia, symbolika i skutki) odgrywa w kształtowaniu społecznej przestrzeni turystycznej.

Nie istnieje nic bardziej przykrego, niż myśl o śmierci lub raczej o jej nieuchronności, o krót-
Abstract: The author's aim is to present the role of death (its conceptions, symbolism and effects) in forming social tourist space. The author presents the history of the perception of death and quotes examples of deathrelated sites which are interesting from a tourist point of view. He also attempts to answer the question why tourists visit places associated with death.

$\underline{\text { Key words: }}$ cultural tourism, death, thanatourism.

The growing interest in travelling in order to see historical monuments, but also more sensitive elements of non-material culture such as tradition, ritual and belief, results in the creation of new often controversial tourist products. The sphere of cultural heritage which touches the sacrum, revered and protected from the interference of elements strange to a given culture, is presently being deprived of mysticism by the increasing commercialisation of life.

Tourism is a phenomenon in which the tourist comes into personal contact with the visited environment, both cultural and social; it is a meeting of cultures, an ex-change of values between the tourists and the local inhabitants; it often becomes a social and cultural change factor (PRZECŁAWSKI 1997). One of the significant elements of culture is death, often considered as a factor which actually creates and maintains a culture alive. The article is an attempt to present the role of death (its conceptions, symbolism and effects) in forming the social tourist space.

The thought of death, its inevitability and 
kotrwałości naszego bycia w świecie. Świadomość śmierci jest i pozostaje traumatyczna. Jednakże tam, gdzie mowa jest o śmierci, pojawia się jednocześnie jej przeciwwaga, a więc odmowa śmierci, mity przetrwania, nieśmiertelność, zmartwychwstanie. Jak mówił Z. Freud, „nikt nie wierzy we własną śmierć". Gdy nie jesteśmy pobudzani lub ponaglani, powracamy do stanu świadomości, w którym myśl o własnej śmierci jest po prostu nieobecna. Żyjemy tak jakbyśmy nie mieli umrzeć. Wielka tradycja religijna i filozoficzna ludów żyjących na różnych szczeblach kultury, na różnych kontynentach i w różnych epokach dysponuje ogromnym zasobem wierzeń i mitów, obietnic i nadziei mających w pewien sposób pogodzić ludzi ze śmiercią, a nawet ukazać im jej sens i wartość (TOYNBEE $i$ in. 1973).

Jak pisze M. VovelLE (2004): „Śledząc kolejne etapy death trip (wędrówki śmierci), od fazy terminalnej aż po cmentarz - nie szukając przy tym na siłę znaczenia - stajemy wobec często przywoływanego problemu rozpadu gestów i zwyczajów oraz poszukiwania nowych rytuałów, będących jedynie skodyfikowaną formą bardziej złożonych wyobrażeń." Przekształcenia te wpłynęły na dzisiejsze popkulturowe zainteresowanie śmiercią, prowadzące do odbywania wycieczek do miejsc $\mathrm{z}$ nia związanych, tzw. t a n a t o t u r y s t y k i (TANAŚ 2006). Śmierć, szczególnie jej wyobrażenie i symbolika, od XIX w. jest walorem wykorzystywanym $\mathrm{w}$ ramach turystyki kulturowej.

Rozpatrując znaczenie śmierci w turystyce należy uzmysłowić sobie fakt, że ,śmierć przeżywana", a więc gesty i rytuały towarzyszące śmiertelnej chorobie, agonii, drodze w zaświaty, wyrażała się najpierw w praktykach pogrzebowych, które miały na celu człowieka pokrzepić: w magicznych, religijnych i świeckich zabiegach, za pomocą których próbowano zawsze śmierć obłaskawić, nadając znaczenie rytuałowi ostatniego przejścia, pogrzebowi, pochówkowi i żałobie strukturę, w której odbijała się niekiedy narzucona postawa wobec śmierci, a częściej dawało się odczytać nawarstwione ślady rozmaitych tradycji (VovelLe 2004). Ślady form ceremoniałów pogrzebowych, które można przypisać już człowiekowi neandertalskiemu należą do najstarszych źródeł poznania postaw wobec śmierci. Obrzędy pogrzebowe są ceremoniałem przeznaczonym do wyrażania czci zmarłym, żalu po stracie zmarłego członka społeczności, wreszcie ukazują one grozę i niepokój wobec faktu samej śmierci the shortness of life is very sad. The awareness of death is always traumatic. However, whenever it comes there also appears the denial of death as its counterbalance, myths of survival, immortality and resurrection. As Freud said, 'nobody believes in his own death'. When we are not stimulated or hurried, we return to a state of consciousness in which the thought of our own death simply does not exist. We live as if we were never to die. The vast religious and philosophical tradition of peoples living on different levels of culture, on different continents and in different times, includes a great number of beliefs and myths, promises and hopes which are in a way to reconcile people with death, and even show them its sense and value (TOYNBEE et al. 1973).

According to VOVELLE (2004), 'Following the consecutive stages of the death journey, from the terminal phase to the cemetery without looking for a meaning at any cost we often face an often quoted problem of disappearing custom and search for new rituals which are frequently only a codified form of more complex conceptions'. This transformation has caused today's popcultural interest in death leading to trips to associated sites i.e. to thanatourism (TANAŚ 2006). Since the 19th c. death, and especially its conception and symbolism, has been an asset exploited in cultural tourism.

Considering the meaning of death in tourism, we must first realize that the experience of death, i.e. gestures and rituals accompanying a terminal illness, agony, going to the other side, was originally expressed through burial practices which were to comfort the man, in magical, religious and secular rituals in which death was always tried to mollify/tame death; the ritual of the last transition, funeral and mourning was given particular significance and structure, reflecting the often imposed attitude to death and preserving traces of various traditions (VOVELLE 2004). Traces of burial rituals practiced by Neanderthal man are among the oldest sources of our knowledge about attitudes to death. Burial rituals are ceremonies during which veneration for the deceased is expressed, as well as sorrow because of the departure of a community member. They also express the horror and fear of death itself (TOYNBEE et al. 1973). 
(TOYNBEE $\mathrm{i}$ in. 1973). Obiekty sepulkralne należą do najstarszych, najliczniej odwiedzanych przez turystów śladów po naszych przodkach. Różnorodność sposobów oddawania czci zmarłym w różnych epokach i różnych regionach jest zadziwiająca i stanowi o zainteresowaniu poznawczym. Zmarłych grzebano w grobach, kurhanach i piramidach. Palono ich na stosach, przechowując prochy $w$ urnach lub rozsiewając na wietrze. Pozostawiano też zwłoki na pożarcie zwierzętom żywiącym się padliną. Bez względu na to, jak różne były obrzędy pogrzebowe, łączyło je wspólne znaczenie - istota ludzka posiada godność $\mathrm{z}$ racji bycia człowiekiem, która trwa nawet po śmierci i dlatego traktowanie zwłok ludzkich winno być wyjątkowe. Zasada ta jednak nie zawsze obowiązuje, np. wobec wrogów, skazańców czy innowierców, ze szczególnym wskazaniem na średniowiecze i nowożytne konflikty zbrojne.

W historii ludzkości postawy i aspekt poznawczy wobec śmierci zmieniały się. Ślady dawnych tradycji, obrzędy, formy pamięci po zmarłym stanowią od wieków element zainteresowania poznawczego, tym istotniejszy im bardziej są wyraziste $\mathrm{w}$ swej ekspresji. Warto wspomnieć o ewolucji postawy wobec śmierci w cyklu życia człowieka. Dziecko rodząc się nie ma świadomości śmierci, dopiero $\mathrm{w}$ wieku kilku lat zapoznaje się z jej faktem i doświadcza reakcji dorosłych na śmierć. Kształtuje się również jego wyobraźnia wobec niej. Dziecko rozumie stosunkowo niewiele ze złożoności naszych wzorców kulturowych dotyczących tematów zakazanych i dopuszczanych. W wiekach dawnych ludzie mogli straszyć dzieci śmiercią realistycznie opisując umieranie, stwarzając możliwości fizycznego kontaktu z umierającym lub umarłym. Współcześnie stwarza się atmosferę zastraszania przez to, że śmierć przemilczamy. Dziecko nie jest izolowane jednak od wyobrażeń o śmierci, a próby jego osłony przed rzeczywistością sprzyjają potęgowaniu się fantazji (TOYNBEE i in.1973). Proces kształtowania percepcji śmierci od dziecka do osoby dorosłej ma wpływ na zainteresowanie śmiercią, jej fantastycznymi obrazami, które w XIX w. przybrały wizerunek duchów, zjaw, stworów opisywanych w literaturze. Trauma wojenna pierwszej połowy XX w. „wyhamowała" zainteresowanie turystyczne śmiercią. Jednak już pokolenie lat 60 . XX w. zderzyło się z nowym wizerunkiem śmierci. G. GORER (1979) zwraca uwagę na popkulturowy wymiar śmierci, sprzyjający w kolejnych dekadach XX w. zainteresowaniu nie tyle śmiercią, co jej makabrycznym,
Sepulchral sites are the oldest and the most frequently visited traces left by our ancestors. The variety of ways of paying homage to the dead in different periods and in different regions is astonishing and very interesting. The dead were buried in graves, burial mounds and pyramids. They were burnt on funeral pyres and their ashes were kept in urns or blown with the wind. Bodies were left for scavengers to eat. Regardless of how different burial rituals were, they had one idea in common - a human being has dignity because of being human. It lasts even after death and therefore human bodies should be treated exceptionally well. This principle, however, was not always binding, e.g. in the case of enemies, convicts or infidels, particularly in the Middle Ages and during modern wars.

Over the history of man, attitudes towards death and its cognitive aspect have been changing. The traces of old traditions, rituals, forms of remembering the dead have interested people for ages, the more so the more expressive they have been. The evolution of the attitude to death in the human life cycle is worth consideration. When a child is born, it is unaware of death, only when it is a few years old, it learns about it and experiences an adults' reac- tion to it. The child's imagination regarding death is formed. $\mathrm{He}$ or she understands relatively little of the complexity of our cultural patterns concerning taboo and per-mitted topics. In past centuries children could be scared by death by realistically describing the act of dying, enabling the child to come into physical contact with a dying or dead person. Today the atmo-sphere of fear is created by not talking about death. However, children are not isolated from conceptions of death, and attempts to keep them away from reality only intensify fantasizing about it (ToYNBEE et al. 1973). The process of forming a perception of death from childhood to adulthood determines an interest in death and its images which in the 19th $\mathrm{c}$. had the form of ghosts, apparitions and beasts described in literature. The war trauma of the first half of the $20^{\text {th }} \mathrm{c}$. decreased the tourist interest in death, but the 1960s generation saw a new face of death. 
komiksowym obrazem. Ten obraz został rozpowszechniony przez kulturę masową, kreującą poglądy na świat i potrzeby poznania tego, co niecodzienne.

Dlaczego turysta odwiedza miejsca związane ze śmiercią, ma potrzebę oglądania ludzkich mumii, kości i czaszek, interesuje się katastrofą i tragedią ludzką? Turystyka kulturowa, obejmująca podróże o motywach poznawczych do miejsc i obiektów o wartości historycznej, artystycznej i kulturowej, wyróżnia się zdobywaniem wiedzy o innych $\mathrm{i}$ ich sposobie życia (kulturze). Jednym z istotnych obszarów poznawczych turystyki kulturowej jest oczywiście aspekt śmierci. Podróżujący turystycznie jednak nie od razu zainteresowani byli odwiedzaniem miejsc związanych z czyją́s śmiercią. Opierając się na poglądach $\mathrm{M}$. VOVELLE'a (2004), ewolucję zainteresowania turystycznego śmiercią można podzielić na trzy etapy:

1. etap - od dyskursu „magicznego” do „religijnego". Etap złożony, trwający od starożytności przez średniowiecze po apogeum klasycyzmu, zdominowany w Europie od XIII w. chrystianizacją śmierci - drogą podboju i walki z magicznymi wierzeniami ludowymi lub, inaczej określając, pogańskimi oraz drogą kompromisu, gdzie religia przejmowała pewne formy obrzędów pogańskich, silniejszych od „nowego" poglądu na śmierć. Zainteresowanie poznawcze śmiercią przede wszystkim w aspekcie religijnym (pielgrzymkowym) i widowiskowym.

2. etap - dyskurs „laicki”, który pojawiał się stopniowo, przybierając różne formy: filozoficzną, naukową, obywatelską. Etap desakralizacji śmierci w dobie triumfu społeczeństw liberalnych. Początek zainteresowania śmiercią podróżujących turystycznie.

3. etap - dyskurs ,literacki” i ,artystyczny”, który w najróżniejszych postaciach, aż po współczesne media, poszerza dotychczasowe tradycyjne ramy śmierci. Etap mistyki, irracjonalizmu i deskrypcji niepokojów. Znaczący wzrost zainteresowania śmiercią podróżujących turystycznie.

Aspekt poznawczy wobec zmarłych i śmierci pojawił się już w starożytności, począwszy od zainteresowania wielkimi nekropoliami afrykańskimi (Egipt, Sudan), krwawymi rzymskimi igrzyskami, będącymi elementem rozrywki, po zainteresowanie rzymskimi i starochrześcijańskimi nekropoliami (Via Appia w Rzymie). Kult śmierci pojawił się $\mathrm{w}$ Europie wraz $\mathrm{z}$ rozwojem kultu męczenników, gdy nad ich grobami zaczęto budować często świątynie, wokół których z czasem pojawiały się kolejne groby. Zarówno kościół， jak
GORER (1979) points to the pop-cultural dimension of death, increasing in succeeding decades of the $20^{\text {th }}$ c. - an interest not so much in death as its macabre, comic image. This image was spread by popular culture, which formed such a view of the world and created the need to learn about the unusual.

Why does a tourist visit places connected with death, have a need to look at mummies, bones and sculls? Why is s/he interested in disaster and human tragedy? In cultural tourism, including journeys to places and buildings of historical, artistic and cultural value, knowledge is gained about others and their way of life (culture). One important cognitive area of cultural tourism is naturally death. Tourists, however, were not always interested in visiting places connected with someone's death and following VOVELLE's theory (2004), the evolution of tourist interest in death can be divided into three stages:

First stage: from 'magical' to 'religious' discourse. It was a complex stage, which lasted from antiquity, through the middle ages, until the peak of classicism, and was dominated by the christianisation of death in Europe from the 13th $\mathrm{c}$. onwards, through conquest and the struggle against magical folk or pagan beliefs, as well as by means of a compromise where religion took on certain pagan rituals, stronger than the 'new' view to death. Interest in death was primarily religious (pilgrimages) and spectacle-oriented.

Second stage: 'secular' discourse which surfaced gradually, assuming different forms: philosophical, scientific, and civil. It was a stage in the desacralisation of death at the time of triumphant liberal societies. It was the time when tourist travellers took an interest in death.

Third stage: 'literary' and 'artistic' discourse, which broadens the scope of death in a variety of ways, including contemporary media. It is a stage of mysticism, irrationality and description of fear. Tourist travellers become greatly interested in death.

Fascination with the dead and death was already present in antiquity, starting from interest in huge African necropolia (Egypt, the Sudan), through bloody Roman circus games, an element of entertainment, to 
i otaczający go cmentarz stał się miejscem publicznym, ,gdzie handlowano, tańczono albo przychodzono po to, by być wśród ludzi" (ARIÈs 2007). Odrodzenie przyniosło zmianę postawy wobec śmierci. Śmierć związana została ze sztuką umierania (artes moriendi), rytuałem posiadającym znaczny ładunek emocjonalny, a przejawiającym się m.in. w sztuce sepulkralnej kościołów.

Dla rozpatrywania znaczenia śmierci w historii turystyki istotny jest etap pojawienia się śmierci w sztuce i literaturze. Wiek XV upowszechnia w ilustracjach, malowidłach kościelnych i na cmentarzach wyobrażenie „Tańca Śmierci”, a XVI stulecie motyw ludzkich zwłok i makabrę w postaci figur przedstawiających ciało zmarłego w stanie rozkładu, tzw. transi (najbardziej znana w Europie figura transi umieszczona jest na grobowcu René de Chalon w Bar le Duc we Francji i pochodzi z połowy XVI w.). Jednocześnie należy wspomnieć o zmianach w postawie wobec grobu. Indywidualne groby starożytnego Rzymu, zbiorowe i anonimowe groby średniowiecza i na powrót indywidualizacja grobu od wieku XIII wraz z upływem czasu obejmowały szersze kręgi społeczeństwa. Wraz ze zjawiskiem indywidualizacji grobu upowszechniła się sztuka sepulkralna, mająca wyraz dzieła artystycznego, tym samym stanowiąca obiekt zainteresowań poznawczych. Począwszy od XVIII w. człowiek w kręgu kultury zachodniej zaczął nadawać śmierci nowy sens. Starał się ją uwznioślić i udramatyzować. Prosty pogrzeb wszedł w fazę uroczystego, przesadnego pogrzebu - pompa funebris, nabierając wymiaru widowiska połączonego $\mathrm{z}$ wyrazistą żałobą i opłakiwaniem. Barok zmienił estetykę śmierci i wykorzystał ciało ludzkie jako element ekspozycji (eksponowanie zwłok zmarłych podczas pogrzebu lub wystawianie na pokaz zmumifikowanych ciał). Szczątki kostne stały się dekoracją świątyń, pojawiła się moda na ossuaria (miejsca gromadzenia szczątków kostnych, dawne kostnice). Jednocześnie śmierć była powszechna w literaturze i malarstwie. Przesadna żałoba była źródłem współczesnego kultu grobów i cmentarzy, stanowiących podstawę rozwoju zainteresowań poznawczych wobec sztuki sepulkralnej i umarłych. Grobowce stały się oznaką pośmiertnej obecności zmarłych, nieśmiertelności w pa-mięci osób żyjących. Kult grobu od samego początku był nie tylko kultem prywatnym, ale stał się jednocześnie kultem publicznym. Osiemnastowieczny cmentarz był jednocześnie parkiem dostosowanym do rodzinnych odwiedzin i muzeum sławnych ludzi (ARIÈS 2007). W Stanach Zjednoczonych pojawiły się pierwsze przejawy po- the interest in Roman and old Christian cemeteries (Via Appia in Rome). The cult of death appeared in Europe along with the cult of martyrs when shrines started to be erected above their graves, sometimes surrounded by other graves. Both the church and the surrounding cemetery became a public place where "people came to trade, dance and socialize' (ARIÈs 2007). The renaissance brought a change of attitude to death. Death was related to the art of dying (artes moriend $\lambda$, an emotionally loaded ritual, and reflected in the church sepulchral art.

In the discussion of the significance of death in the history of tourism, it is important to consider the stage when it appeared in art and literature. The $15^{\text {th }} \mathrm{c}$. popularized the image of the dance of death in illustrations, church paintings and at cemeteries, and the $16^{\text {th }} \mathrm{c}$. introduced the motif of the human corpse and the macabre in the form of figures presenting a decomposing dead body - transi (the most famous transi figure in Europe can be found in the tomb of Rene de Chalon in Bar-leDuc, France and comes from the middle $16^{\text {th }} \mathrm{c}$.). We should also mention the changing attitude to the grave itself. With time, the individual graves of ancient Rome, the collective and anonymous graves of the middle ages and again individual graves from the $18^{\text {th }}$ c. onwards concerned an increasing part of society. Along with the individualisation of graves, the popularity of sepulchral art grew; it became a subject of interest. Starting from the $18^{\text {th }} \mathrm{c}$., the man of the western culture gave death a new sense. He tried to uplift and dramatize it. A simple funeral entered the phase of a solemn, exaggerated ceremony - the pompa funebris - becoming a spectacle combined with open mourning. The baroque changed the aesthetics of death and used the human body as an element of exposition (displaying dead bodies during funerals or showing mummified bodies). Bone remains became an element of shrine decoration, ossuaries came into fashion (places where bones were stored, former mortuaries). At the same time death was widely appearing in literature and painting. Exaggerated mourning was the source of today's cult of graves and cemeteries which triggered 
śmiertnego kultu bohatera narodowego $\mathrm{W}$ postaci monumentalnych ,pustych grobowców” stanowiących cel podróży turystycznych (mauzolea Thomasa Jeffersona i George'a Washingtona). Wiek XIX stał się również okresem romantycznych fantazmatów kreujących popyt na ,atrakcje turystyczne" związane ze śmiercią.

Pierwsza połowa XX w. przyniosła diametralną zmianę w postawie wobec śmierci. Śmierć niegdyś wszechobecna stopniowo znikła ze świadomości, stając się rzeczą wstydliwą i zakazaną. Człowiek przestał umierać we własnym domu, umierał w szpitalu. Śmierć przestała być rytualną ceremonią, stała się zjawiskiem technicznym. W tym samym czasie nastąpiła gwałtowna przemiana w kulturowej postawie człowieka Zachodu wobec śmierci. Śmierć została odrzucona. Ph. ARIÈs (2007) zwraca uwagę na bezpośrednie przyczyny tego faktu: potrzebę szczęścia, moralny obowiązek i społeczny nakaz kreowania szczęścia zbiorowości przez usuwanie wszelkich powodów do smutku czy zmartwienia i sprawianie wrażenia, że jest się szczęśliwym, choćby się było w najgłębszej rozpaczy. Rozwój w XX w. kultury masowej i mediów spowodował, że śmierć innych stała się bliższa. Śmierć ponownie jest niewyczerpalnym źródłem opowieści i podlega preparacji komiksowej.

Upowszechnienie podróżowania $\mathrm{w}$ celach turystycznych spowodowało zwiększenie dostępności do odmienności. Sposób patrzenia na świat uzależniony jest od społeczeństwa i epoki historycznej, a spojrzenie turysty definiuje różnica. J. URRY (2007) zwraca uwagę na zależności pomiędzy spojrzeniem turysty na świat a tym, co jest jego przeciwieństwem, tym, co w danym momencie jest doświadczeniem nieturystycznym. Turoperatorzy, organizatorzy i animatorzy produktów turystycznych poszukują nowych, ciekawych miejsc „Zwabiających” turystów i będących odpowiedzią na zainteresowanie turystyką. Turysta kieruje uwagę tam, gdzie widzi różnice od tego, co codzienne. Współczesny sposób przeżywania, rola poznawcza i estetyczna zależą od wrażeń wzrokowych. W tym m.in. należy upatrywać zwiększony stopień zainteresowania miejscami związanymi ze śmiercią, jej aktem i symboliką. Historia percepcji śmierci uzmysławia jej wagę w rozwoju turystyki kulturowej oraz wskazu- je na to, że zainteresowanie poznawcze śmiercią nie jest nowe.

Wszystkie społeczności nakłaniają swoich członków do okresowego, a nawet codziennego uczestnictwa w aktach zbiorowej pamięci. Rytu- interest in sepulchral art and the dead. Tombs became a symbol of presence after death, of immortality in the memory of the living. From the very beginning the cult of graves was not only private, but also public. The $18^{\text {th }} \mathrm{c}$. cemetery was at the same time a 'park' suited to family visits and a museum of famous people (ARIĖs 2007). In the United States the first signs of the cult of dead national heroes appeared in the form of monumental 'empty tombs' to which tourists travelled (Thomas Jefferson's and George Washington's mausoleums). The 19th $\mathrm{c}$ also became the time of romantic phantasms, creating a demand for 'tourist attractions' related to death.

The first half of the 20th $\mathrm{c}$. brought a radical change in the attitude to death. Once omnipresent, death gradually disappeared from human consciousness becoming a shameful and forbidden thing. Man stopped dying in his own home; now he died in hospital. Death stopped being a ritual, it became a technical phenomenon. At the same time there came a rapid transformation of the cultural attitude of Western man towards death. Death was rejected. ARIĖs (2007) points to the direct reasons for this: the need for happiness, the moral and social obligation to care about the happiness of a community by eliminating all potential reasons for sadness or concern, and by creating an impression that someone is happy even if they are completely devastated. The development of popular culture and the mass media in the $20^{\text {th }} \mathrm{c}$. made the death of others more familiar. It is again an endless source of tales, and subject to comic preparation.

The popularization of travel for tourist purposes made the unusual more accessible. Outlook on the world depends on the society and historical period, and the tourist's outlook is defined by the difference. URRY (2007) points to the relation between the tourist's view of the world and that which is its opposite, a non-tourist experience at any given moment. Tour operators, tourist product organizers and animators search for new, interesting places attracting tourists and satisfying the demand for tourism. The tourist goes where he sees something different from everyday 
ał pamięci oddziela moment śmierci cielesnej od momentu śmierci społecznej, nadając marzeniu o nieśmiertelności określoną formę materialną lub niematerialną. Rytuał pamięci jest istotnym elementem poznania w turystyce kulturowej. Uniwersalna, ponadhistoryczna i ponadkulturowa obecność rytuałów pogrzebowych oraz zrytualizowanych obchodów pamięci zmarłych była wielkim odkryciem etnografii. Nie odnaleziono żadnej formy życia ludzkiego, nawet najbardziej prymitywnej, gdzie nieprzestrzegano by jakiegoś wzorca narzucającego konieczność troszczenia się o ciało zmarłych i podtrzymywania ich pośmiertnej obecności w pamięci potomnych. Różnice $\mathrm{w}$ rytuałach pogrzebowych są motorem potrzeby poznania wśród odwiedzających m.in. cmentarzyska i nekropolie. Obietnica nieśmiertelności stała się najsilniejszym narzędziem dyscypliny $w$ rękach społeczeństwa. Podobnie jak inne społecznie rozdzielane nagrody, nieśmiertelność może być „rozdawana” w mniejszym lub większym stopniu $\mathrm{w}$ zależności od posiadanych przez zmarłych cnót, które społeczeństwo stara się uwiecznić. Nieśmiertelność ta objawia się począwszy od publicznej żałoby, przez słowo mówione, tekst pisany, obraz, pomnik, nazwę ulicy i szlaku, muzea i inne formy upamiętnienia materialnego i niematerialnego, stanowiące cel poznania żyjących. Rytuały i ceremonie pamięci jawią się jako kod. Im bardziej są skomplikowane $\mathrm{i}$ poruszające, $\mathrm{z}$ tym większą siłą przyciągają uwagę zbiorowości. Kandydaci do nieśmiertelności muszą przedstawić trwałe ślady swoich działań: czyny na tyle istotne, aby można było je osadzić w tradycji, przedmioty na tyle cieka- we, by uznać je za sztukę, myśli na tyle oryginalne, by mieć podstawę do ich przyjęcia (BAUMAN 1998).

Gdyby ludzie nie byli świadomi swej śmiertelności, najprawdopodobniej nie byłoby kultury. E. MORIN (1996) twierdzi wręcz, że kultura jest „niebezpiecznym napojem miłosnym, odwracającym uwagę od śmierci. Najczystszym wyrazem kultury jest grobowiec egipski, gdzie próżno poniewierają się narzędzia, klejnoty, żywność, obrazy, rzeźby i modlitwy, a człowiek i tak nie żyje”. Muzealizacja życia powodowała gromadzenie $\mathrm{w}$ jednym miejscu odnalezionych resztek dorobku nieżyjących. Jednakże w XX w. postępował upadek klasycznego modelu kultury, opartego na magazynowaniu wytworów myśli i pracy. Nie bez znaczenia dla tego procesu jest „kultura masowa", która rozwija się w bardzo szybkim tempie od lat 60. XX w. „Kultura masowa” wypełnia czas wolny (przez widowiska, telewizję, radio, lek- experience. Today's way of experiencing things and the cognitive and aesthetic role depend on visual impressions. Here we should look for an explanation to the growing interest in places related to death, the act and symbolism of it. The history of death perception makes us aware of its importance in the development of cultural tourism and suggests that interest in death is not a new phenomenon.

All societies try to persuade their members to take part in temporary or even everyday acts of remembrance. The ritual separates the moment of bodily death from the moment of social death, giving the dream of immortality either a material or nonmaterial form. The ritual of remembrance is an important element of cognition in cultural tourism. The universal presence of burial rituals and the ritualized remembrance of the dead, going beyond history and culture, was a great ethnographical discovery. Researchers did not find any form of human life, even among the most primitive, without some kind of pattern which obliged people to care about the bodies of their dead and to maintain their post-mortem presence for the memory of following generations. Differences between burial rituals trigger the need to visit burial sites and cemeteries. The promise of immortality became the most powerful tool in the discipline of society. Similar to other social rewards, immortality can be 'granted' to a greater or lesser extent, depending on the dead person's virtues which the society tries to immortalize. Immortality is manifested in public mourning, in the spoken and written word, in images, monuments, names of streets or routes, museums, and other forms of material and non-material commemoration which the living want to learn about. Rituals and ceremonies occur as a code. The more complicated and moving they are, the stronger they attract the community's attention. Prospective immortals must leave permanent evidence of their activity; deeds important enough to be incorporated into tradition, objects interesting enough to be considered art, and thoughts original enough to be adopted by others (Bauman 1998).

If people were not aware of their 
turę dzienników i czasopism). Nasyca czas wolny treściami kulturowymi tak, że staje się stylem życia (MORIN 1965). Widzenie typowo współczesne to widzenie telewizyjne, kiedy widzi się wszystko zawsze w zbliżeniu, ale to co się widzi, jest zarazem nieuchwytne i oddalone. Tak postrzegana jest współcześnie śmierć również przez turystę odbywającego wycieczki poznawcze. Turysta masowy jest często odizolowany od miejscowego środowiska naturalnego, cieszy się z nieautentycznych, wymyślonych atrakcji, naiwnie czerpiąc z nich przyjemność, wielokrotnie niedostrzegając otaczającej go rzeczywistości. Często podświadome zainteresowanie śmiercią prowadzi do pojawienia się potrzeby zobaczenia jej następstw i tego, co w krajobrazie po sobie zostawia. Im bliższy kontakt ze śmiercią, tym ciekawiej, zarazem mało który turysta chce doświadczyć jej bezpośrednio, jednocześnie izolując fakt jej istnienia.

Ludzkie podróżowanie narodziło się $\mathrm{z}$ fenomenu pielgrzymki do miejsc świętych, w tym do grobów świętych. Współczesna podróż jest ustandaryzowana, opakowana i sprzedana jako produkt. Głównym celem turystyki jest odwiedzanie atrakcji turystycznych, przyciągających turystów ze względu na swoje szczególne cechy. „Ceną uatrakcyjnienia podróży turystycznych jest niejednokrotnie redukcja bogactwa lokalnej kultury do stereotypów" (PODEMSKI 2004). W ten sposób m.in. można opisać turystyczną chęć oglądania miejsc ,przesiąkniętych” śmiercią, gdzie turysta zaspokaja potrzeby emocjonalne i estetyczne przeżycia przygody i ryzyka, przy jednoczesnym ,spłyconym” i ograniczonym stopniu percepcji ,kultury śmierci", opartej przede wszystkim na wrażeniach wzrokowych.

W ramach turystyki kulturowej odbywają się podróże, której celem jest szeroko pojęta „przestrzeń śmierci”, z której można wyodrębnić m.in. przestrzeń sepulkralną (grobową, cmentarną, związaną ze zmarłym). W tej przestrzeni funkcjonują miejsca, obiekty, wydarzenia stanowiące przedmiot zainteresowań turystycznych (STASIAK, TANAŚ 2005).

Cmentarz jest pewnym wycinkiem przestrzeni, w ramach której realizowana jest przez określoną społeczność praktyka grzebania zwłok zmarłych, odpowiadająca wyznaniowym, etniczno-kulturowym i innym potrzebom danej społeczności (KolBuszewsKi 1996). Cmentarz jest efektem realizacji wyższego rzędu potrzeb kulturowych. $Z$ tego względu nekropolie mają istotne znaczenie $\mathrm{w}$ zaspokajaniu przez turystów potrzeb po- mortality, culture would most probably not exist. MORIN (1996) claims that culture is 'a dangerous love potion, distracting man from death. The purest expression of culture is an Egyptian tomb, filled with tools, jewels, food, paintings, sculptures and prayers, while the man is dead anyway.' The 'musealisation' of life resulted in gathering the remains of the dead people's property in one place. However, the $20^{\text {th }} \mathrm{c}$. was the time when the classical model of culture, based on pre-serving the outcome of thought and work, was gradually collapsing. 'Popular culture', which rapidly developed in the 1960s, played quite an important role here. Pop culture fills free time (performances, television, radio, newspapers and magazines). It filters into it so much that it becomes the style of life (MORIN 1965). The typical con-temporary perception is that of television, when everything is seen in close-up, but what is seen is at the same time elusive and distant. This is also the way death is perceived by the contemporary tourist. Such a tourist is often isolated from the local natural environment, enjoying non -authentic, pre-organized attractions, naively drawing pleasure from them, and often ignoring the surrounding reality. A subconscious interest in death often leads to the need to see its consequences and what it leaves behind in the landscape. The closer the contact with death, the more interesting the experience becomes; at the same time hardly any tourist wants to experience death directly, denying its existence.

Human travel was born out of pilgrimage to holy sites including the graves of saints. Today's travel is standardized, wrapped and sold as a product. The main aim of tourism is to visit places which are attractive and interesting due to their particular qualities. Making tourist travel attractive often reduces the richness of local culture to stereo-types' (PODEMSKI 2004). In this way we can describe the willingness to visit places 'saturated' with death, where the tourist satisfies his emotional and aesthetic need to experience adventure and risk at a limited level of 'death culture' perception, based primarily on visual impressions.

Journeys into 'death space', which in- 
znawczych związanych $\mathrm{z}$ poznawaniem kultury własnej lub innej. Walory poznawcze cmentarza to w rzeczywistości jego infrastruktura stanowią-ca o jego charakterze. Składa się na nią wiele elementów, które razem tworzą architektoniczną tożsamość nekropolii. Cmentarz jako przestrzeń spotkania (KACZMAREK 2002) to m.in. znaczenie dziedzictwa historycznego w dziejach społeczeństwa, poszanowanie dla tradycji, budowanie pamięci regionalnej, spotkanie z ideami i losami innych ludzi, tworzenie rodzinnej pamięci, odkrywanie własnej tożsamości, poszukiwanie sensu bycia. Wymienione cechy cmentarza są ważne ze względu na możliwość wykorzystania jego przestrzeni na potrzeby turystyki kulturowej i edukacji. Z tego powodu cmentarz, jako specyficzny wycinek przestrzeni społeczno-geograficznej, odgrywa istotną rolę w kształtowaniu osobowości turysty. Przykładami obiektów stanowiących przed-miot zainteresowań turystycznych są: Cmentarz Père Lachaise Paryż (Francja), cmentarz Ohlsdorf - Hamburg (Niemcy), Stary Cmentarz - Zakopane (Polska), „Wesoły Cmentarz" - Sapinta (Rumunia), Narodowy Cmentarz Arlington (Stany Zjednoczone), cmentarz Recoletta - Buenos Aires (Argentyna).

Grób jest obiektem, który ma dokładnie wskazywać gdzie złożono ciało. Grób wyznacza bardzo dokładnie miejsce kultu żałobnego oraz przekazuje następnym pokoleniom pamięć o zmarłym. Grób lub jego zewnętrzna forma - grobowiec - jest źródłem wiedzy historycznej. Motywy odwiedzin grobów mogą być bardzo różne. $\mathrm{Z}$ punk- tu widzenia turystyki są to przede wszystkim: religijny, poznawczy (edukacyjny, krajoznawczy) i komemoratywny. Piramidy, sarkofagi, kurhany, płyty grobowe, ścienne tablice, epitafia, pomni- ki, nagrobki, będące obrazem rozwijającej się sztuki sepulkralnej, są wybitnymi działami sztuki, księgami historii ludzkiej i stanowią jednocześnie o atrakcyjności turystycznej miejsca. Wystarczy wspomnieć piramidy egipskie, sarkofagi rzymskie, groby męczenników, świętych, duchownych, władców i wybitnych postaci, tablice nagrobne i epitafia, barokowe pomniki czy eklektyczne monumentalne grobowce cmentarne lub inne formy upamiętnienia, jak chociażby groby symboliczne i pomniki ku czci nieżyjących.

Świątynia jest obiektem przeznaczonym do realizowania praktyk religijnych żywych. Jednak od VI w. w kręgu kultury chrześcijańskiej aż do wieku XIX w kościołach masowo pojawiały się groby. Zabytkowy kościół jest wielokrotnie miejscem przesiąkniętym śmiercią i jej symboliką, począwszy od ołtarzy, polichromii, obrazów, po cludes sepulchral space (graves, cemeteries), with its places, buildings and events which are of interest to the tourist (STASIAK $\&$ TANAŚ 2005), are part of cultural tourism.

A cemetery is a fragment of space where a given community buries their dead according to certain religious, ethnic, cultural and other standards (KolBUSZEWSKI 1996). The cemetery is an effect of cultural needs of a higher order. Therefore cemeteries play an important role in satisfying the tourists' needs as regards learning about a culture - their own or other. The educational asset of the cemetery consists in fact in its infrastructure which determines its character. It consists of many elements which together create the architectural identity of the necropolis. The cemetery as a meeting space (KACZMAREK 2002) embodies, among other things, the significance of historical heritage in the history of a society, respect for tradition, the building up of regional memory, contact with the ideas and lives of other people, the creation of family memory, the discovery of one's own identity, and search for the meaning of life. The qualities of the cemetery mentioned above are important because its space can be exploited to cater for the needs of culture tourism and education. The cemetery, as a particular fragment of socio-geographical space, plays an important role in forming the tourist's personality. Some examples of sites which are of interest to tourists include Père Lachaise in Paris (France), Ohlsdorf in Hamburg (Germany), the Old Cemetery in Zakopane (Poland), the 'Jolly Cemetery' in Sapinta (Romania), Arlington National Cemetery (the USA) and Recoletta in Buenos Aires (Argentina).

The grave is to indicate exactly where a body has been buried, it points precisely to the place of mourning and hands the memory of the deceased down to succeeding generations. The grave, or its outside form the tombstone, is a source of historical knowledge. The motives for visiting graves are very different: religious, educational or commemorative. Pyramids, sarcophagi, burial mounds, tombstones, wall tablets, epitaphs, monuments, and gravestones presenting current sepulchral art which are exquisite pieces of art and 'books' of human history, determine the tourist attractiveness of a place. The Egyptian pyramids, 
tablice, sarkofagi, pomniki, płyty nagrobne umieszczane w posadzce oraz krypty. Turysta odwiedzający kościół obcuje ze śmiercią, ogląda symbolikę śmierci, sztukę sepulkralną stanowiącą wielokrotnie o randze zabytkowej obiektu. Krypty bardzo często stanowią miejsce, gdzie eksponowane są trumny, sarkofagi, zmumifikowane zwłoki lub dekoracje pogrzebowe.

Dla określonych grup społecznych trup związany jest najczęściej $\mathrm{z}$ wyobrażeniem, jakie sobie o nim tworzą, stanowi obiekt szczególnej percepcji, fantazmaty, jakie wywołuje wyrażają się rozmaicie $\mathrm{w}$ zależności od panujących systemów społeczno-kulturowych i społeczno-ekonomicznych. Najbardziej operatywne rozróżnienie oddziela społeczeństwa archaiczne lub tradycyjne, bogatsze w znaki i symbole od zindustrializowanych społeczeństw nowoczesnych (THOMAS 2001). Związane $\mathrm{z}$ umarlym fantazmaty uzasadniają rozmaite obrzędy, których staje się przedmiotem oraz sposoby obchodzenia się z nim (zniszczenie, konserwacja, zabezpieczenie). W wieku XVII pojawiło się przekonanie, że umarły nie może po prostu zniknąć, że coś w nim pozostaje, że trzeba go konserwować i że dobrze jest go pokazywać i oglądać. Krypta kościelna stała się więc nie tylko miejscem przechowywania trumien i zwłok poddanych rytualnej czci, lecz również miejscem widowiska odwiedzanym $\mathrm{z}$ czystej ciekawości zobaczenia zmumifikowanych ciał ludzkich. Podobnie ossuaria, pierwotnie będące jedynie miejscem składowania szczątków ludzkich pochodzących ze starych grobów, zamieniły się w XVII w. w rodzaj dekoracji, w której koś- ci ludzkie poddano wszelkim wymysłom sztuki barokowej i rokokowej, gdzie „pokazuje się ludzki szkielet niczym maszynerię teatralną i on z kolei oglądany jest niczym widowisko" (ARIÈs 1989). To, co miało swoisty wymiar sacrum w XIX w., przekształciło się $\mathrm{W}$ przedmiot zainteresowań, oglądany przez żądnych emocji turystów. Tego typu miejsc jest stosunkowo niewiele, ale sa cenione jako wybitne dzieła sztuki. Do grupy obiektów $\mathrm{z}$ wyeksponowanymi mumiami, zwłokami lub szczątkami kostnymi odwiedzanych przez turystów należy zaliczyć m.in.: kościół Kordelierów w Tuluzie (Francja), kościoły Kapucynów w Palermo i Santa Maria della Concezione w Rzymie (Włochy), katakumby w Paryżu (Francja), kaplicę Wszystkich Świętych w Sedleci k. Kutnej Hory (Czechy), katakumby kościoła św. Stefana w Wiedniu (Austria), katakumby św. Franciszka w Limie (Peru), kościół św. Michała w Bordeaux (Francja), kaplice Kości w Evorze i Faro (Por-
Roman sarcophagi, graves of martyrs, saints, spiritual men, rulers and distinguished people, grave plaques and epitaphs, baroque monuments or eclectic monumental cemetery tombs, or other forms of commemoration, such as symbolic graves and tombstones in honour of the dead can be mentioned.

A shrine is a place where live religious practices take place. However, from the $6^{\text {th }}$ to the $19^{\text {th }} \mathrm{c}$. in Christian culture graves commonly appeared in churches. An old church is saturated with death and its symbols in many ways, starting from the altars, polychromic decoration and paintings through to tablets, sarcophagi, tombstones, to grave plaques placed in the floor and to crypts. The tourist visiting a church communes with death, observes its symbols and sepulchral art, which often determines the historical rank of the church. Crypts are often places where coffins, sarcophagi, mummified bodies or funeral decorations are displayed.

To given social groups, a dead body is usually connected with an image they create, it is perceived in a special way, the phantasms it brings are expressed in a variety of ways, depending on sociocultural and socio-economic systems. The biggest difference can be found between archaic or traditional societies, rich in signs and symbols, and modern industrial societies (THOMAs 2001). The phantasms related to the dead justify various rituals and the way the body is treated (destruction, conservation, securing). In the $17^{\text {th }} \mathrm{c}$ people started to believe that a deceased person cannot simply disappear, that something stays in the body so it must be conserved and it should be displayed and looked at. The church crypt became then not only a place where coffins and corpses were stored, but also a performance site, visited out of sheer curiosity to see mummified human bodies. The same happened with ossuaries where originally human remains from old graves were stored. In the $17^{\text {th }} \mathrm{c}$. they changed into a kind of decoration where human bones were subject to all possible ideas of baroque and rococo art, in which the human skeleton is presented as a piece of theatre machinery and watched like a performance' (ARIĖs 1989). What used 
tugalia), kaplicę św. Michała w Hallstatt (Austria), kaplicę św. Michała w Oppenheim (Niemcy), kościół św. Błażeja w Vodnjan (Chorwacja). Polskimi przykładami są m.in: Kaplica Czaszek w Czermnej, krypta klasztorna benedyktynów na Świętym Krzyżu w Górach Świętokrzyskich, krypty w kościele oo. Reformatów w Krakowie, Kaplica św. Krzyża we Wschowie. Do grupy tej należy zaliczyć również ossuaria stawiane na terenie obozów koncentracyjnych, zagłady lub na polach bitewnych, np. Majdanek (Polska), Douaumont k. Verdun (Francja), Tuol Sleng (Kambodża).

Innym rodzajem podobnych ekspozycji są wystawy mumii egipskich (Muzeum Egipskie w Kairze, Muzeum Brytyjskie w Londynie) i zakonserwowanych ciał ludzi prehistorycznych, np. w Muzeum Mumii Guanajuato (Meksyk), Narodowym Muzeum Grenlandii w Nuuk, Muzeum Brytyjskim w Londynie. Zwłoki w całości lub ich fragmenty są również przedmiotami kultu religijnego i świeckiego. W tradycji europejskiej kult świętych oraz zwyczaj tworzenia i przechowywania relikwii jest przykładem dzielenia się cielesnymi szczątkami zmarłych. Najbardziej spektakularne są wystawione zabalsamowane zwłoki w przezroczystych sarkofagach, np. św. Bernadetty w Lourdes (Francja), św. Katarzyny Laboure w Paryżu (Francja), św. Franciszka Ksawerego w Goa (Indie), Jana Baptysty Marii Viena w Ars (Francja), św. Zyty w Lucca (Włochy), Lenina w Moskwie (Rosja).

Komercyjne wykorzystanie zwłok jest ciekawym zagadnieniem z punktu widzenia zachowań kulturowych. Na świecie jest wiele przykładów wystawiania na pokaz zabalsamowanych ciał. Współcześnie najbardziej znaną mobilną wystawą jest wystawa Gunthera von Hagensa „Body Worlds", która przez 10 lat istnienia zgromadziła ok. 25 mln widzów w Azji, Europie i Ameryce Pn. (www.bodyworlds.com). Wystawom takim towarzyszy zawsze atmosfera sensacji i zainteresowanie mediów, co w efekcie generuje zjawisko „komercjalizacji śmierci”. Skutkiem tego postępuje systematycznie desakralizacja ludzkich zwłok, które stały się przedmiotem wyizolowanym ze swojego pierwotnego, pogrzebowego kontekstu (GRYGLEWSKI 2005).

Eksponaty związane ze śmiercią są często prezentowane $\mathrm{w}$ muzeach, na wystawach podczas obrzędów i ceremonii. Najczęstszą przyczyną gromadzenia przedmiotów jest czynnik dokumentacyjny i archiwizujący dziedzictwo kulturowe. Najbardziej znane muzea sepulkralne to: Wiedeńskie Muzeum Pogrzebu, Narodowe Muzeum Pogrzebu to have a particular sacrum dimension, turned into an attraction watched by tourists hungry for emotion. There are not many places like that, but they are appreciated as exquisite pieces of art. Here are examples of places where mummies, dead bodies or bone remains are exhibited for tourists: the Cordelier church in Toulouse (France), the Capuchin churches in Palermo and Santa Maria della Concezione in Rome (Italy), the catacombs in Paris (France), All Saints' Chapel in Sedleci near Kutna Hora (the Czech Republic), the catacombs in St Steven's church in Vienna (Austria), St Francis catacombs in Lima (Peru), St Michael's church in Bordeaux (France), the Chapels of Bones in Evora and Faro (Portugal), St Michael's Chapel in Hallstatt (Austria), St Michael's Chapel in Oppenheim (Germany), and St Błażej church in Vodnjan (Croatia). Polish examples include the Chapel of Skulls in Czermna, the crypt in the Benedictine monastery at the Holy Cross in the Swiętokrzyskie Mountains, the crypts in the church of the Order of the Reformati in Krakow, and the Holy Cross Chapel in Wschów. The ossuaries built on former concentration camps or battlefields, e.g. Majdanek (Poland), Douaumont near Verdun (France), or Tuol Sleng (Cambodia) can also be menioned.

Another kind can be found in the exhibitions of Egyptian mummies (the Egyptian Museum in Cairo, the British Museum in London) and preserved prehistoric bodies, e.g. in the Guanajuato museum of mummies (Mexico), the National Museum of Greenland in Nuuk, or the British Museum in London. Whole bodies or parts of them are objects of both religious and secular cult. In the European tradition, the cult of the saints and the custom of creating and preserving holy relics are forms of sharing the bodily remains of the dead. The most spectacular are embalmed corpses displayed in trans-parent sarcophagi, e.g. that of St Bernadette in Lourdes (France), St Catherine Labouré in Paris (France), St Francis Xavier in Goa (India), Jean Baptist Maria Vien in Ars (France), St Zyta in Lucca (Italy), and Lenin in Moscow (Russia).

The commercial use of corpses is an in- 
w Paryżu, Muzeum Ohlsdorf w Hamburgu, Muzeum Kultury Sepulkralnej w Kassel, Narodowe Muzeum Pogrzebu w Londynie, Narodowe Muzeum Pogrzebu w Huston. Polskimi przykładami są z pewnością wystawa portretów trumiennych w Muzeum Regionalnym w Międzyrzeczu i XVIII-wieczna „sala śmierci” w Pałacu Biskupa Erazma Ciołka w Krakowie. Należy wspomnieć również o wystawach czasowych poświęconych tematyce śmierci, jak np. wystawa, „Vanitas. Portrety trumienne na tle sarmackich obyczajów pogrzebowych" zorganizowana przez Muzeum Narodowe w Poznaniu, która okazała się wielkim wydarzeniem artystycznym, gromadząc $\mathrm{w}$ ciągu trzech miesięcy ok. 50 tys. odwiedzających (STASIAK, TANAŚ 2005).

Wskazana w artykule rola śmierci w turysty- ce kulturowej oraz podane przykłady miejsc związanych ze śmiercią, będących przedmiotem zainteresowań turystycznych, wskazują jedynie na istotę problemu badawczego t a n a t o t u r y s t y ki. Niewątpliwie turystyczne zainteresowanie śmiercią wiąże się z poglądem J. URRY'ego (2007), że turysta prawdziwego życia szuka za kulisami, gdzie pozostaje ukryte przed wzrokiem intruzów, a jego spojrzenie polega na wdzieraniu się w cudze życie, w tym przypadku w cudzą śmierć, bez zachowania odpowiedniego dystansu, co w normalnych warunkach byłoby nie do przyjęcia. Problem wykorzystania sacrum śmierci na potrzeby tworzenia produktu turystyczne- go zajmuje coraz większą rzeszę badaczy z różnych dyscyplin naukowych, co świadczy o istotności zjawiska w szeroko rozumianej turystyce kulturowej. teresting issue from the point of view of cultural behaviour. There are many examples when embalmed bodies have been put on display and today the most famous mobile exhibition is that of Gunther von Hagens, entitled 'Body Worlds', which in 10 years has been seen by about 25 million people in Asia, Europe and Northern America (www.bodyworlds.com). Such exhibitions always take place in an atmosphere of sensation and are of great interest to the media. This has led to the commercialization of death and as a result to the gradual desacralization of dead human body now isolated from its primary funeral context (GRYGLEWSKI 2005).

Objects connected with death are often exhibited in museums, during rituals and ceremonies and the most common reason for collecting them are to substantiate and archive cultural heritage. The best known sepulchral museums are the Vienna Museum of Funeral, the National Museum of the Funeral in Paris, Ohlsdorf Museum in Hamburg, the Museum of Sepulchral Culture in Kassel, the National Museum of Funeral in London and the National Museum of Funeral in Houston. Among Polish examples there is the exhibition of coffin portraits at the regional museum in Miedzyrzecze, and the $18^{\text {th }} \mathrm{c}$. 'Hall of Death' at Bishop Erazm Ciołek's palace in Kraków. We should also mention temporary exhibitions devoted to death such as the Vanitas: coffin portraits and noblemen's funeral customs' exhibition, organized by the National Museum in Poznan which turned out to be a great artistic event attracting about 50 000 visitors over three months (STASIAK \& TANAŚ 2005).

The role of death in cultural tourism discussed here, as well as examples of sites connected with death and interesting to tourists, merely touch upon the essence of the research focus in thanatourism. Tourist interest in death certainly corresponds to URRY's claim (2007) that the tourist searches for true life behind the curtains where it remains hidden from intruders' eyes. This 'glance' is an intrusion into someone else's life, in this case someone's death, without keeping the distance which in normal conditions would be 
found acceptable. The issue of using the sacrum of death for creating a tourist product is studied by a growing number of specialists from different academic disciplines demonstrating the significance of the phenomenon in cultural tourism.

\section{BIBLIOGRAFIA - BIBLIOGRAPHY}

ARIÉs Ph., 1989, Człowiek $i$ śmierć, Państwowy Instytut Wydawniczy, Warszawa.

ARIÉs Ph., 2007, Rozważania o historii śmierci, Oficyna Naukowa, Warszawa.

BAUMAN Z., 1998, Śmierć i nieśmiertelność. O wielości strategii życia., Wydawnictwo Naukowe PWN, Warszawa.

Gorer G., 1979, Pornografia śmierci, Teksty 45 (3).

GRYGLEWSKI R. W., 2001, Mumifikacja ciała ludzkiego $w$ świetle historii obyczajów i nauki, Kraków.

KACZMAREK J., 2002, Nekropolie jako przestrzeń kultury, [w:] E. Orłowski (red.), Kultura jako przedmiot badań geograficznych. Studia teoretyczne i regionalne, Oddział Wrocławski PTG, Uniwersytet Wrocławski, Wroclaw, 75-86.

Kolbuszewski J., 1996, Cmentarze, Wydawnictwo Dolnośląskie, Wrocław.

MoRIN E., 1965, Duch czasu, Znak, Warszawa.

MoRIN E., 1996, Prowincja ludzka, Wydawnictwo Śląskie, Wrocław.
PODEMSKI K., 2004, Socjologia podróży, Wydawnictwo Naukowe Uniwersytetu Adama Mickiewicza, Poznań.

PRZECEAWSKI K., 1996, Człowiek a turystyka. Zarys socjologii turystyki., ALBIS, Kraków.

STASIAK A., TANAŚ S., 2005, Przestrzeń sepulkralna w turystyce, Turystyka i Hotelarstwo, 8, 9-42.

TANAŚ S., 2006, Tanatoturystyka - kontrowersyjne oblicze turystyki kulturowej, Peregrinus Cracoviensis, 17, 85100.

Thomas L.V., 2001, Trup. Od biologii do antropologii, Wydawnictwo ETHOS, Warszawa.

TOYnBeE A. Mant K., Smart N., Hinton J., Yudkin S., 1973, Człowiek wobec śmierci, Państwowy Instytut Wydawniczy, Warszawa.

URRY J., 2007, Spojrzenie turysty, Wydawnictwo Naukowe PWN, Warszawa.

VovelLe M., 2004, Śmierć $w$ cywilizacji Zachodu, Słowo/ Obraz/Terytoria, Gdańsk. 